\title{
Underground thermal energy storage in subarctic climates: a feasibility study conducted in Kuujjuaq ( $Q C$, Canada)
}

\author{
Nicolò Giordano \\ Chrystel Dezayes
}

Inès Kanzari

Jasmin Raymond
Mafalda M. Miranda

\begin{abstract}
Underground thermal energy storage can provide space and water heating and has been used in temperate climates so far. A step forward is to evaluate the efficiency and viability in arctic to subarctic environments, where rather low ground and air temperatures can make the design of such systems difficult. The present contribution describes the design of an underground storage system in Kunjuaq (Québec, Canada) to heat the drinking water distributed in the town. The system was designed and modeled with TRNSYS and a parametric study was carried out to improve its efficiency based on 5-year simulations. The 20\% of the $425 \mathrm{MWh}$ annual demand can be satisfied by a solar collector area of $500 \mathrm{~m}^{2}$ coupled to a 10,000 $\mathrm{m}^{3}$ underground storage through two short term tanks. Further improvements could be adopted to reach the target of $50 \%$ energy from the underground store.
\end{abstract}

\section{INTRODUCTION}

Kuujjuaq is the regional capital of Nunavik, the Québec territory standing north of $55^{\text {th }}$ parallel. Nunavik inhabitants amount to around 12,300, Kuujjuaq being the most populated village with 2375 people. All the villages rely on fossil fuels to produce both electricity and heat. Power plants fueled by diesel provide electricity with production prices ranging between 0.5 and $1.1 \mathrm{USD} / \mathrm{kWh}$, with Kuujjuaq standing near the average at $0.6 \mathrm{USD} / \mathrm{kWh}$, while in the other parts of Québec on-grid and off-grid production costs about 0.02 and $0.3 \mathrm{USD} / \mathrm{kWh}$, respectively (Hydro-Québec, 2011). Space heating (SH) and domestic hot water (DHW) in Nunavik are commonly achieved autonomously in each building equipped with furnaces. The subsidized cost of diesel in Nunavik was on the order of 1.6 USD/liter in 2015 and a common diesel furnace with $80 \%$ efficiency provides space heating with a cost of $0.19 \mathrm{USD} / \mathrm{kWh}$ (Belzile et al., 2017). Energy production and utilization appear critical in Nunavik. New developments to cover the energy needs of these communities are needed to diminish the high economic costs and environmental impact, as well as reducing fuel transportation in these hostile and fragile environments up north.

Renewable energy offers an opportunity to use local resources and detailed studies are being carried out in Northern Québec to evaluate the potential of geothermal technologies as a tool to meet the objectives of the action plan for sustainable development and reduce the greenhouse gas emissions (MDDELCC, 2012). The feasibility of exploiting both deep and shallow geothermal resources is being evaluated to provide heat for SH and DHW in Nunavik through enhanced geothermal systems and deep borehole heat exchangers (BHE; Miranda et al., 2018), as well as ground source heat pumps (GSHP) and borehole thermal energy storage systems (BTES). Underground storage systems, further described in this study, are a mature technology (Schmidt et al. 2004; Xu et al., 2014; Cabeza,

Nicolò Giordano (nicolo.giordano@ete.inrs.ca) is a post-doc fellow, Inès Kanzari is a master student, Mafalda M. Miranda is a PhD student and Jasmin Raymond is a Professor: they all work at the Institut national de la recherche scientifique - Centre Eau Terre Environnement (INRS-ETE) in Québec City, Canada. They are also members of the Centre d'études nordiques (CEN). Chrystel Dezayes is a research fellow at the Bureau de Recherches Géologiques et Minières (BRGM) in Orléans, France. 
2015; Sibbitt et al., 2012) that can help solar thermal energy to be exploited throughout the whole heating season. Solar fraction (solar energy to total need ratio) can be easily higher than $50 \%$ and in some cases it was demonstrated to reach up more than $90 \%$ (Flynn and Sirén, 2015; Gao et al., 2015). Despite several demonstrations throughout the world in different climate contexts, to the best of our knowledge, a BTES system has not been tested in subarctic environment yet, where the SH demand is characterized by more than $8000 H D D_{18}$ as in Kuujjuaq (Governement of Canada, 2018).

The Kativik Regional Government, an administrative authority in Nunavik dealing with northern infrastructure, pointed out the drinking water facility in Kuujjuaq to be an important target for the community to reduce the use of fossil fuels. Currently the water is withdrawn from the Stewart Lake and heated on site by diesel furnaces to prevent freezing along the underground pipeline toward a reservoir building in the village. Here, the water is collected by tanker trucks and hence distributed to each house. A rough estimate shows that the cost of water heating amounts to about 80,000 USD/year (truck diesel consumption excluded). The scope of this contribution is to design a BTES system to partially cover the pumping station's heating needs. Transient simulations with TRNSYS (Klein et al., 2017) have been carried out to optimize the system and anticipate its thermal behavior in the Kuujjuaq climate setting.

\section{GEOGRAPHICAL AND GEOLOGICAL SETTING}

Kuujjuaq $\left(58.10^{\circ} \mathrm{N},-68.42^{\circ} \mathrm{E}\right)$ is the main Inuit village in Nunavik among the 14 First Nations communities placed along the coasts of the Ungava peninsula, surrounded by the Hudson Bay (W), the Hudson Strait $(\mathrm{N})$ and the Ungava Bay (E; Fig. 1). Kuujjuaq shows a subarctic climate with average annual air temperature of $-5.8^{\circ} \mathrm{C}$ and $8520 H D D_{18}$. Mean solar radiation from May to September is $4.5 \mathrm{kWh} / \mathrm{m}^{2} \mathrm{~d}$ and mean temperature from October to April is $-14{ }^{\circ} \mathrm{C}$ (1981-2010 Normals, Governement of Canada, 2018). A temperature increasing trend is nevertheless clear from $1990\left(-7^{\circ} \mathrm{C}\right)$ to $2010\left(-3.5^{\circ} \mathrm{C}\right.$; Fortier et al., 2011). The presence of discontinuous but widespread permafrost is reported in the region (Allard and Lemay, 2012) and it strongly depends on the local geological conditions (Lemieux et al., 2016).

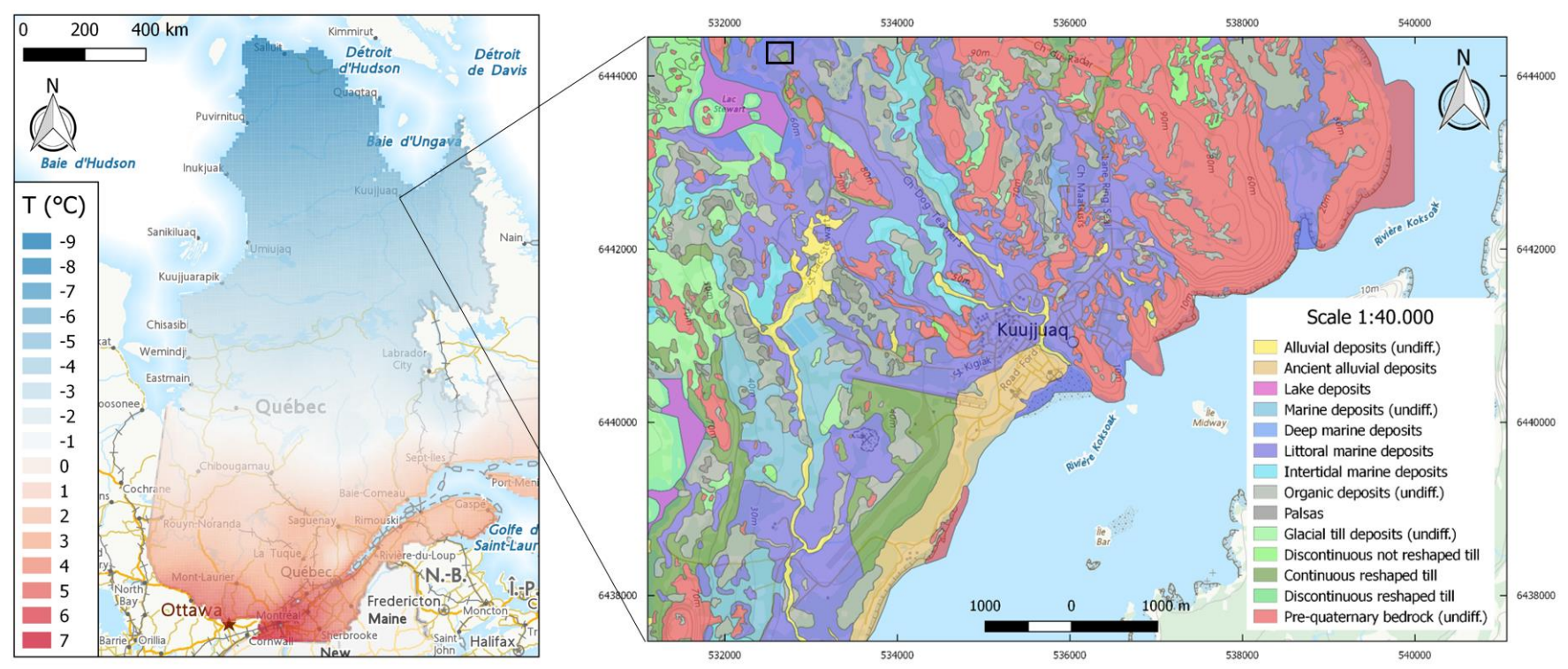

Figure 1 Geographical and geological setting of the examined area (modified from Fortier et al., 2011). The left map shows the average annual air temperature. The black rectangle in the right map highlights the study area. (Coordinate system NAD83/UTM Zone 19N). 
The study area is located in the west part of the Southeastern Churchill Province (Simard et al., 2013 and references therein). The quaternary sediments mainly consist of littoral and pre-littoral sediments alternating to intertidal deposits related to different cycles of transgression and regression of the Iberville Sea (Fortier et al., 2011). Glacial till deposits often cover bedrock outcrops and it is common to find them underlying the marine sediments. Alluvial coarse-grained materials are only found along the small streams of two valleys with streams flowing toward the Kosoak River. A field campaign was carried out in Kuujjuaq in the summer 2017. Surveys involved rocks and quaternary sediments samples collection, temperature logs in wells, in situ hydraulic conductivity tests and electrical resistivity tomography (ERT) investigations. A detailed description of these field surveys is reported in Giordano et al. (2017) and Miranda et al. (2018); only the most important results for the aim of this contribution are described here.

The two ERT lines carried out on the site of the pumping station showed saturated marine deposits overlying glacial till sediments on the top of the bedrock (Giordano et al., 2017), whose presence is highlighted south of the examined area (Fig. 1). Local evidence of frozen ground was not identified by the ERT (investigation depth $20 \mathrm{~m}$ ), even if the groundwater temperature was measured around $1{ }^{\circ} \mathrm{C}$ away from surface water bodies. The proximity of the Stewart Lake, the coarse-grained sands and the groundwater advection contribute together to locally prevent freezing in this unit, that is not affected by permafrost. The thermal properties of the quaternary sediments were measured in the lab with a needle probe (Raymond et al., 2017). The saturated marine deposits have a thermal conductivity of $1.5 \mathrm{~W} / \mathrm{mK}$ and a heat capacity of $3.0 \mathrm{MJ} / \mathrm{m}^{3} \mathrm{~K}$ (Giordano et al., 2017).

The BTES system was therefore designed to be hosted in the saturated marine sediments, providing an optimal storage medium with moderate to low heat transfer characteristics. The local groundwater flow was also investigated during the field activities because it plays a critical role in the evaluation of the heat losses by advection (Diersch et al., 2011; Nguyen et al., 2017). However, it is not presented and developed further on in this paper because it is believed to deserve a detailed analysis beyond the scope of this first study.

\section{MATERIALS AND METHODS}

The pumping station at the Stewart Lake withdraws water from the lake all year long and in winter the temperature is almost constant at around $4{ }^{\circ} \mathrm{C}$. Before being pumped in the pipeline at a flow rate of $36 \mathrm{~m}^{3} / \mathrm{h}$, the water is heated up to around $7{ }^{\circ} \mathrm{C}$ to prevent freezing during its $4.8 \mathrm{~km}$ way down to the village. Currently, the heating system is fed by two diesel boilers with a nominal capacity of $100 \mathrm{~kW}$. It was assumed that the plant works $16 \mathrm{~h} / \mathrm{d}$ for 7 months (October to April) and thus requires approximately 1525 GJ (425 MWh). The system was designed according to the guidelines of Pahud (2000), that define collector area, short-term and ground storage volumes depending on the heating loads of the final user. According to these guidelines, the annual heat demand of the pumping station can be covered by $2.4 \mathrm{~m}^{2}$ of solar panels per $\mathrm{MWh}$. The idea presented here is to cover $50 \%$ of the demand (210 MWh) and thus around $500 \mathrm{~m}^{2}$ of total solar surface would be necessary.

The ground storage strongly depends on the thermal and hydraulic properties of the underground. In this perspective, the reference ground storage has been designed having 100 boreholes with a single U-pipe to a depth of $30 \mathrm{~m}$, divided in 20 series of 5 BHE hydraulically connected in parallel, in a cylindrical shape disposition with $3 \mathrm{~m}$ spacing ( $\sim 22,000 \mathrm{~m}^{3}$, radius $15 \mathrm{~m}$, shape factor $(S F)$ equal to 1$)$. Considering heat conduction as the only governing mechanism, an increase of the ground temperature by 10,20 or $30^{\circ} \mathrm{C}$ would allow to store 660,1320 and 1980 GJ, respectively. To achieve the target of $760 \mathrm{GJ}$, the plant is expected to raise the temperature of the entire underground storage volume by at least 19,23 or $29{ }^{\circ} \mathrm{C}$ considering a storage efficiency of $60 \%, 50 \%$ or $40 \%$, respectively.

The solar and BTES loops are coupled together through a cylindrical short-term storage tank (STST) and the heat carrier fluid (HCF) consists of a mixture of water and 50\% vol. of propylene glycol (minimal working temperature $-30{ }^{\circ} \mathrm{C}$ ) to prevent freezing. The water withdrawn from the lake passes within the STST through a coiled immersed heat exchanger (HX), as proposed by Rad et al. (2017), in order to heat the water in the winter. The last part of the whole system (Fig. 2) consists of a back-up auxiliary diesel boiler (capacity $80 \mathrm{~kW}$ ) to raise the water temperature up to the target $7{ }^{\circ} \mathrm{C}$, in order to satisfy the remaining $50 \%$ of the demand not covered by the BTES. 
The system charges the ground from May to September and retrieves the energy from October to April. For simplicity, the water withdrawn from the lake is considered to be at $4{ }^{\circ} \mathrm{C}$ all year long and the flow rate of the water distribution network runs $24 \mathrm{~h} / \mathrm{d}$ per 7 months at $2 / 3$ of the actual flow $\left(24 \mathrm{~m}^{3} / \mathrm{h}\right)$. During the charge phase, the solar collectors produce energy that is sent to the underground storage via the STST and the BHEs distribute the heat from the center to the outer zones of the storage volume. In the discharge, thermal energy is extracted from the BTES, with the HCF flowing from outer to inner zones, and transferred to the tank while the solar loop is not working.

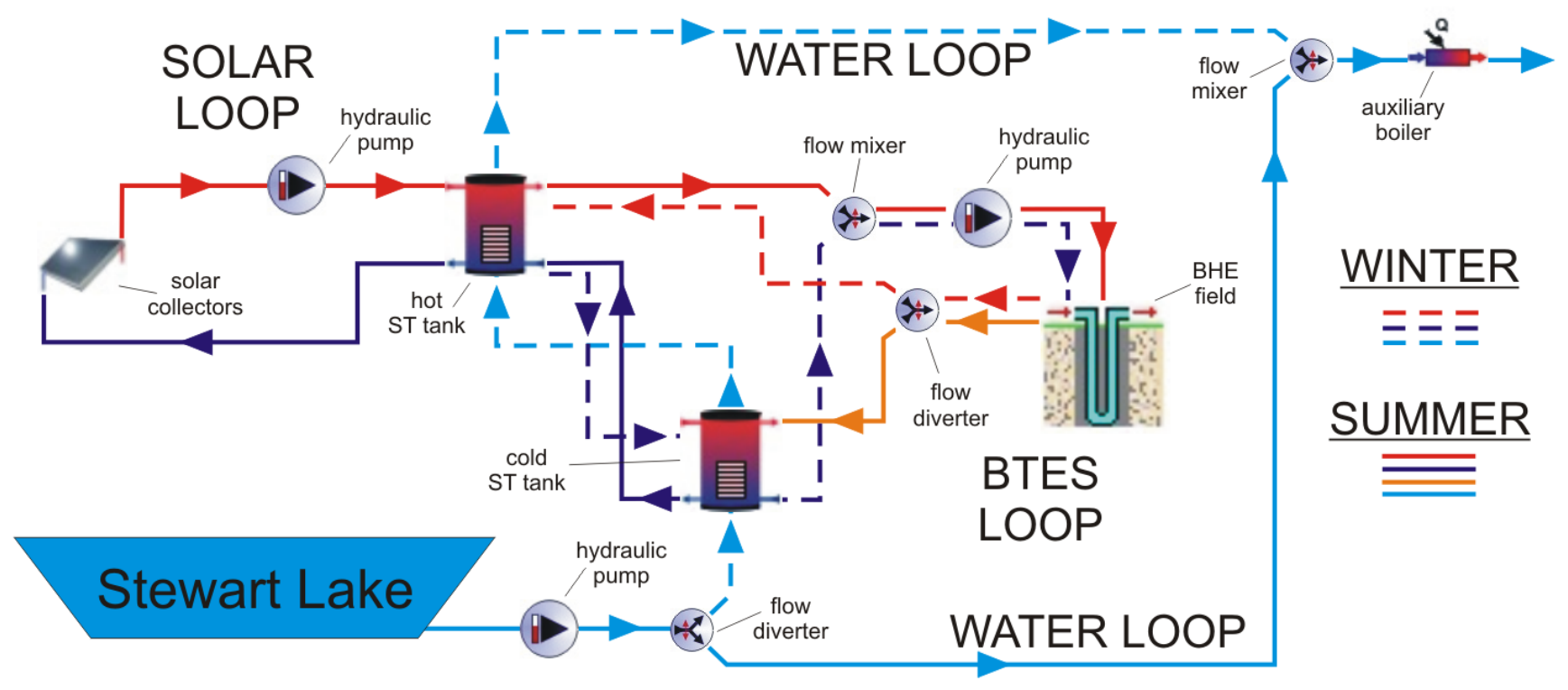

Figure 2 Sketch of the BTES system as designed in scenarios 2 and 3. Light blue color refers to the water loop; red, orange and dark blue gives an idea of the HCF relative temperature throughout the circuit.

\section{TRNSYS MODEL}

TRNSYS is a commercial simulation modular environment that allows the transient modeling of complex energy systems (Klein et al., 2017). Several different components (Types) are individually solved by single systems of equations and then coupled together to achieve the final outputs required by the user. The code has been widely adopted to simulate underground thermal energy storage systems in the last 20 years (e.g. Pahud, 2000; Diersch et al., 2011; Sibbitt et al., 2012; Terziotti et al., 2012; Flynn and Sirén, 2015; Rad and Fung, 2016), using the duct ground heat storage (DST) model developed by Hellström (1989) to simulate BHE operation. The DST is a cylindrical shaped storage volume with a vertical symmetry axis where the BHEs are assumed to be uniformly placed. Convective heat transfer in the ducts and conductive heat transfer in the ground are simulated together to output the whole ground temperature, where three different problems are solved numerically with the finite difference method in the ground (global and local temperature) and analytically in the BHE pipes (steady state problem). The total temperature is achieved by the superposition of the three parts as to ensure a fast and accurate simulation tool (Hellström, 1989).

The whole BTES system described in Fig. 2 was implemented in TRNSYS 18. The main Types used are:

- Type 557a is the currently available type to model the ground storage through the DST. Ten radial regions and ten vertical regions were adopted for the finite difference simulation. The boreholes are conventional $152 \mathrm{~mm}$ size with single $\mathrm{U}$-pipe $\left(d_{0}=32 \mathrm{~mm}\right)$. A $1-\mathrm{m}$ top insulation layer $(\lambda=0.05 \mathrm{~W} / \mathrm{mK})$ and $0{ }^{\circ} \mathrm{C}$ as undisturbed ground temperature were assigned to the model;

- Type 534 was chosen to simulate the STST, a vertical cylindrical storage tank with immersed HX giving the 
needed flexibility on the number of inlets and outlets (up to 10), number and type of immersed HX (up to 5) and number of nodes (up to 20) to increase the model complexity and consider water stratification. A $5 \mathrm{~m}$ height tank with volume of $100 \mathrm{~m}^{3}$ was chosen, two inlets and outlets were selected to connect the solar and BTES loops; one coiled heat exchanger $\left(d_{i}=50 \mathrm{~cm}, \lambda_{\mathrm{HX}}=40 \mathrm{~W} / \mathrm{mK}\right)$ hosts the water distribution loop and twenty nodes provide high accuracy to the simulation;

- Type $1 \mathrm{~b}$ was chosen for the solar panels. It simulates a flat-plate solar collector with quadratic efficiency, $a_{0}=$ $0.8, a_{1}=13 \mathrm{~kJ} / \mathrm{hm}^{2} \mathrm{~K}$ and $a_{2}=0.05 \mathrm{~kJ} / \mathrm{hm}^{2} \mathrm{~K}^{2}$. The total collector area is $500 \mathrm{~m}^{2}$, divided in 125 series of 4 collectors and specific flow rate of around $50 \mathrm{l} / \mathrm{sm}^{2}$;

- Type 6 was selected to simulate the auxiliary diesel boiler with a maximum heating power of $80 \mathrm{~kW}$ and a target outlet temperature of $7{ }^{\circ} \mathrm{C}$;

- Typical meteorological year (Type 15) from the Kuujjuaq airport weather station was selected to provide crucial input weather data to the solar panels and the storage volume.

Table 1. Features of the different scenarios

\begin{tabular}{|c|c|c|c|c|c|}
\hline & SC1 & SC2 & SC3 & SC4 & SC5 \\
\hline Number of ST tanks (-) & 1 & 2 & 2 & 2 & 2 \\
\hline BTES volume $\left(\mathrm{m}^{3}\right)$ & 22,000 & 22,000 & 9500 & 9500 & 9500 \\
\hline BHE spacing (m) & 3 & 3 & 2 & 2 & 2 \\
\hline$S F(-)$ & 1 & 1 & 1.5 & 1.5 & 1.5 \\
\hline Use of second ST tank (-) & - & $\begin{array}{l}\text { Charge + } \\
\text { discharge }\end{array}$ & $\begin{array}{l}\text { Charge + } \\
\text { discharge }\end{array}$ & Discharge & Discharge \\
\hline Pre-heating period $(y)$ & 0 & 0 & 0 & 0 & 1 \\
\hline Preheating $T\left({ }^{\circ} \mathrm{C}\right)$ & - & - & - & - & 10 \\
\hline
\end{tabular}

The features described above characterize the base model that was implemented to simulate the dynamic behavior of the system for five years, interchanging charge and discharge phases. A parametric study was then carried out to optimize the system, mainly focusing on the characteristics of the BTES volume and related parameters. Five different scenarios (SC) were created by modifying one parameter at each step (Tab. 1), but keeping the changes made in the previous scenario in order to aim at a performance increase from SC1 to SC5. A second ST tank (same volume) was added in SC2 to improve the stratification and decrease the BTES inlet temperature. SC3 is a case with a higher storage shape factor (1.5 vs. 1.0) while, in SC4, the second tank was used during the discharge phase only. A 1-year preheating period was finally tested in SC 5 to raise the ground temperature by $10^{\circ} \mathrm{C}$.

\section{RESULTS}

The simulation results generally show the system to progressively provide more energy to the drinking water network from the first to the fifth year, showing a transient condition before reaching an equilibrium. This is clearly highlighted is terms of temperature at the center of the BTES volume in Fig. 3, where it is evident that the time necessary to reach a steady state between injection and extraction strongly depends on the system's characteristics. The underground temperature in SC 1 rises from $0{ }^{\circ} \mathrm{C}$ to about $13-14{ }^{\circ} \mathrm{C}$ at the end of the first injection phase. Then, the maximum value increases each year reaching about $22^{\circ} \mathrm{C}$ in the fifth, but clearly not being the equilibrium yet. SC3 takes advantage of a smaller volume (less than half of SC1, see Tab. 1) and reaches more than $20{ }^{\circ} \mathrm{C}$ already at the end of the first charge year. The maximum in the last year is $3-4{ }^{\circ} \mathrm{C}$ higher than $\mathrm{SC} 1$, meaning that an equilibrium is almost reached between years four and five. SC5 is almost immediately at a steady state, showing that a $10{ }^{\circ} \mathrm{C}$ preheating is sufficient to make the system working properly. It is also clear that SC3 and SC5 tend toward a balanced heat exchange with the underground when compared to SC1, as highlighted by the temperature decrease in the discharge phase that is almost comparable with the increase during the system charge (Fig. 3). This is related to a 
smaller subsurface volume involved in heat exchanges, but also to the use of a second tank that, as we discuss later on, enables to extract more energy by keeping the BTES inlet temperature low. The temperature difference between center and edges of the volume is roughly constant throughout the five years of simulation, ranging between 3 and $4{ }^{\circ} \mathrm{C}$ at the peak of the charge and 0 and $1{ }^{\circ} \mathrm{C}$ (almost no difference) at the end of the discharge for SC3 and SC5. The scenario SC1 shows smaller values in the charge $\left(2^{\circ} \mathrm{C}\right)$ and higher in the discharge $\left(1{ }^{\circ} \mathrm{C}\right)$ owing to a bigger volume involved.

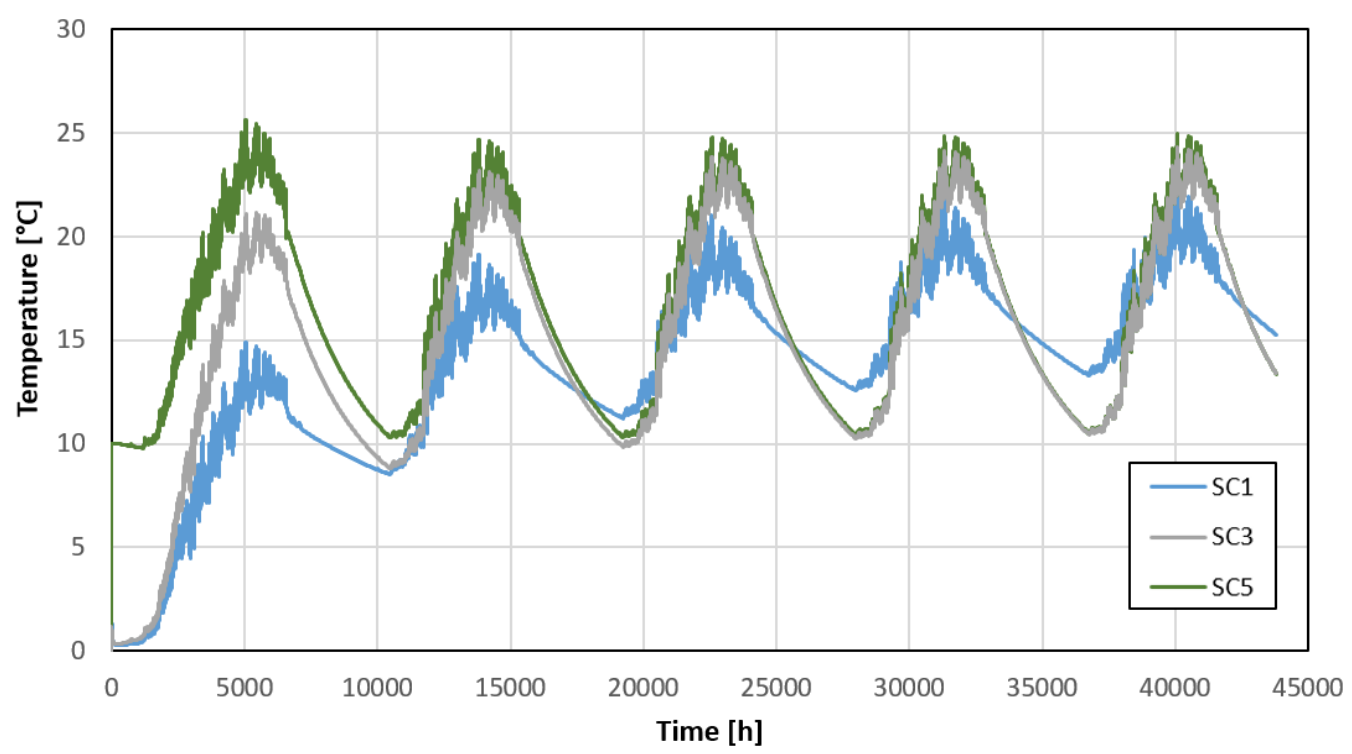

Figure 3 Temperature at the center of the BTES system for 5 years of simulation of scenarios 1, 3 and 5. SC2 and SC4 present trends similar to SC1 and SC3 respectively. They were not added to the graph to make the understanding clearer.

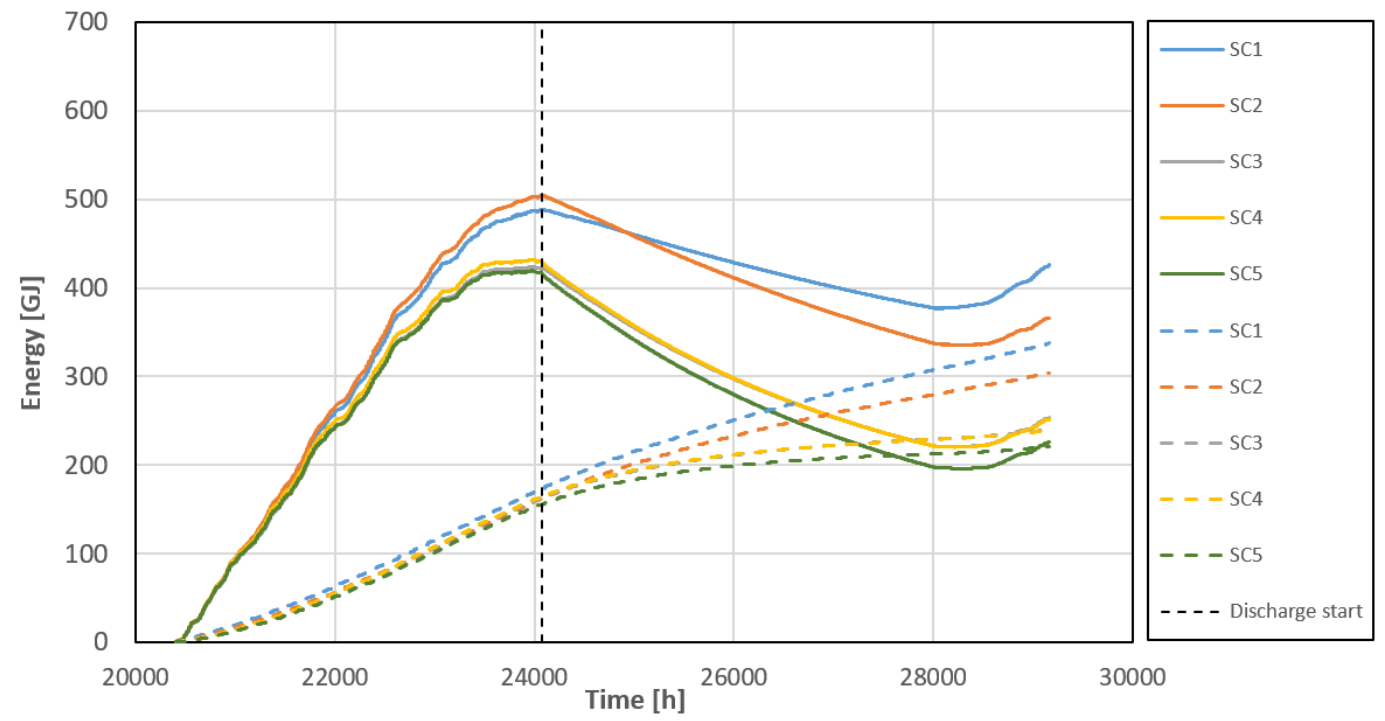

Figure 4 Normalized energy balance for the different scenarios in the third year. Continuous lines indicate the energy injection or extraction while dashed lines indicate the total energy losses. 
A comparison among the energy injected and extracted was done by subtracting the value at the beginning of the period under exam as a normalization useful to highlight the differences among the five scenarios (Fig. 4). The systems conceived in SC1 and SC2 are able to inject about 16\% and 21\% more energy than the others, but they struggle to retrieve that energy in the winter. Indeed, only $22 \%$ and $32 \%$ of those amounts are recovered at the end of the discharge and almost 380 and 340 GJ each year are not used, making the whole storage systems not exploited at their full capacity. In any case, it is worth noticing that the addition of a second ST tank to the system significantly improves the performance, with SC2 injecting 3\% more heat and retrieving $53 \mathrm{GJ}$ more $(+50 \%)$. This is possible because the second tank manages to keep the BTES inlet temperature 1.5 to $2{ }^{\circ} \mathrm{C}$ lower than the case with just one tank (SC1). Another important improvement is achieved by halving the underground storage volume, that is to say by reducing the spacing between the BHEs and thus increasing the SF. The storage of SC3 collects less (-17\%) and loses more energy than SC2, but it clearly recovers the total amount of net energy available (injected - losses) and generates a valid balance between injection and extraction. Further modifications implemented in SC4 and SC5 do not provide significant better performance, the efficiency of the storage volume being just 5\% better in SC 5 . The idea of using the cold tank only in the winter does not allow to further reduce the BTES inlet temperature: SC3 and SC4 are perfectly superimposed in the discharge period (Fig. 4) and give similar values in Tab. 2. The preheating period that differentiates SC4 and SC5 only helps to reach an earlier equilibrium, but the 1\% better recovery highlighted in the third year would not really economically justify the preheating, during which the system would not provide energy. The total heat losses shown in Fig. 4 mostly occur through sides and bottom of the underground storage volume, while losses toward the atmosphere are negligible because of the top insulation layer at low conductivity. It is clear that this trend is similar to all the scenarios during the charge. On the other hand, a marked difference between SC1/SC2 and SC3/SC4/SC5 is observed. Losses are smaller in the first group and similar to those of the charge phase; in the second group, losses keep occurring in the discharge phase but represent less than $20 \%$ of the total heat lost. This happens because the storage volume is half that of SC1 and SC2 and the energy can be recovered more easily.

Table 2. Energy balances for the third year of BTES operation

\begin{tabular}{cccccccc}
\hline & \multicolumn{3}{c}{ Underground Charge } & \multicolumn{2}{c}{ Underground Discharge } & \multicolumn{2}{c}{ Total Energy } \\
\hline \hline & $\begin{array}{c}\text { Injected } \\
(\mathbf{G J})\end{array}$ & Lost (GJ) & Lost $\mathbf{( \% )}$ & $\begin{array}{c}\text { Extracted } \\
(\mathbf{G J})\end{array}$ & $\begin{array}{c}\text { Recovered } \\
\mathbf{( \% )}\end{array}$ & $\begin{array}{c}\text { Aux. boiler } \\
\mathbf{( M W h )}\end{array}$ & BTES (\%) \\
\hline \hline SC1 & 486 & 178 & 36.7 & 105 & 21.7 & 51 & 11.8 \\
SC2 & 501 & 167 & 33.3 & 158 & 31.6 & 73 & 16.9 \\
SC3 & 417 & 167 & 39.9 & 190 & 45.7 & 82 & 19.0 \\
SC4 & 420 & 168 & 40.0 & 194 & 46.2 & 83 & 19.2 \\
SC5 & 407 & 159 & 39.1 & 204 & 50.1 & 86 & 20.0 \\
\hline
\end{tabular}

Scenarios 3 to 5 ended up to cover 19 to $20 \%$ of the total energy demand necessary to heat up the water at the pumping station (Tab. 2), providing 61 to $68 \%$ more energy with respect to the base case SC1. A better view of the amount of energy provided by the auxiliary system to reach the target of $7{ }^{\circ} \mathrm{C}$ is shown in Fig. 5 for the third year of the four most interesting scenarios (SC3 gives the same results of SC4 as shown in Fig. 4). The average heating load supplied by the diesel boiler is around $75 \mathrm{~kW}$ in SC1, where the water is going out of the STST at a maximum temperature of $4.4^{\circ} \mathrm{C}$ at the beginning of the discharge phase and then stabilizes at $4.3^{\circ} \mathrm{C}$. The water is heated up to a maximum of $4.6^{\circ} \mathrm{C}$ and a stable value of $4.4^{\circ} \mathrm{C}$ when a second tank is added to the system, with a maximum load of $70 \mathrm{~kW}$. The flow of water through the first "cold" tank provides nearly the same temperature increase generated in SC1. The water is heated up to a maximum of $5.0^{\circ} \mathrm{C}$ in SC4 and SC5 to cover around $25 \%$ of the demand for almost a month (more than $600 \mathrm{~h}$ ). Close to springtime, the auxiliary loads are basically the same as in SC2.

It is indeed worth noticing the negative trend of the water temperature that tends to stabilize and increase toward the end of the discharge near $27,500 \mathrm{~h}$ and vice versa for the heating loads. This temperature trend is sharper 
in scenarios with two STST. A consistent observation is also clear in Fig. 4, where the negative trend of the energy curve switches to positive for the last $1000 \mathrm{~h}$ of discharge simulation. This happens because the average temperature in the hot tank increases with the restart of the solar production, supplying energy together with the BTES. Kuujjuaq actually receives high daily solar radiation in March $\left(3.2 \mathrm{kWh} / \mathrm{m}^{2} \mathrm{~d}\right)$ and April $\left(5 \mathrm{kWh} / \mathrm{m}^{2} \mathrm{~d}\right)$, which are however listed fourth and fifth as the coldest months, with mean air temperature of about $-17^{\circ} \mathrm{C}$ and $-10^{\circ} \mathrm{C}$. As a comparison, August and September have solar radiation of 3.9 and $2.3 \mathrm{kWh} / \mathrm{m}^{2} \mathrm{~d}$ and mean air temperature of $7{ }^{\circ} \mathrm{C}$ and $3{ }^{\circ} \mathrm{C}$, respectively.

Finally, the target of covering $50 \%$ of the drinking water network energy demand has not been achieved yet, but some improvements were achieved through the optimization of the system (from 12 to $20 \%$ of the demand satisfied). The most important technical adjustments were the addition of a second ST tank, in order to keep the BTES inlet temperature as low as possible during the discharge, and the decrease of the spacing between the BHEs from 3 to 2 $\mathrm{m}$. The latter actually decreased the nominal storage capacity of the underground, but it was shown to be critical in the ability of the system to retrieve the energy $(+20 \%)$ because of the low ground thermal conductivity at the site. The performance of the whole system can be further improved by adding a second immersed HX in each tank in order to extract a larger amount of the energy available in the STST, adding a HX on the solar loop side in order to use a less viscous and more effective HCF with 25\% vol. glycol in the BTES and STST or choosing more efficient solar panels.
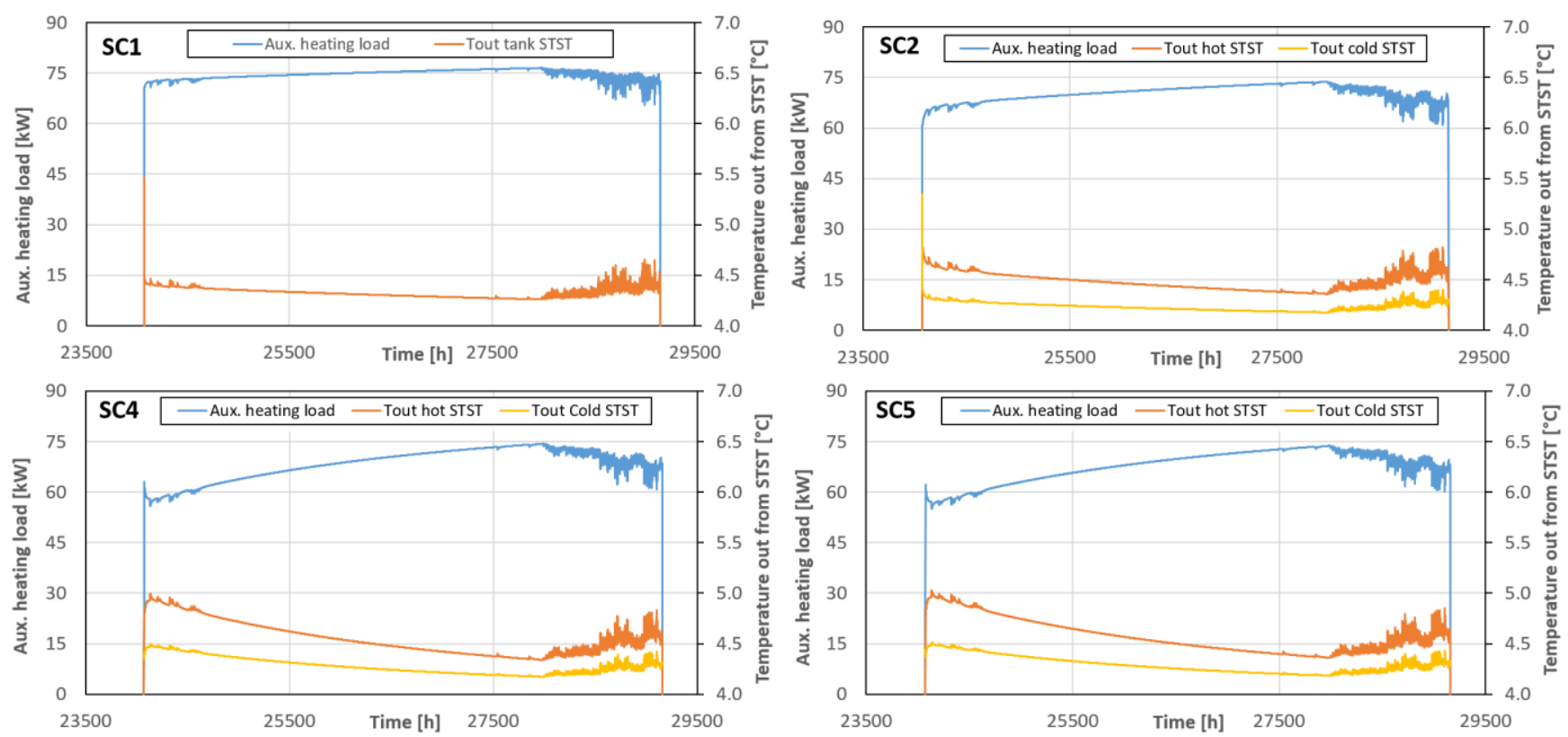

Figure 5 Heating loads provided by the auxiliary system compared to the temperature of the drinking water loop after passing through the cold and hot tanks. Discharge phase at the end of the third year (same period as in Fig. 4).

\section{CONCLUSIONS}

The present contribution showed a feasibility study for the construction of an underground storage system in Kuujjuaq, an Inuit village characterized by a subarctic environment with underground temperature near $0{ }^{\circ} \mathrm{C}$. After developing a geological conceptual model based on the results of various field activities, a BTES system was designed and implemented in TRNSYS to run five-year simulations and vary different characteristics to increase the efficiency of the storage volume. 
Even if improvements were achieved through the optimization of the system and other improvements can be further undertaken, it is clear that the guidelines of Pahud (2000) adopted to desing the system (Pahud, 2000) are not valid for this subarctic climatic context. The guidelines are valid for Swiss conditions, but were adopted because they are useful to define the relative amounts of collector area, short-term and ground storage. However, the collector area should be increased to account for the smaller solar radiation and the low annual air temperature, the latter significantly influencing the thermal collectors' efficiency. To this regard, specific studies are anticipated to propose similar rules for subarctic to arctic climates.

Moreover, the performance of small diameter ground heat exchangers will be evaluated (e.g. $d_{B H E}=76 \mathrm{~mm}$ and $d_{o}=27 \mathrm{~mm}$ ) in order to exploit drilling technology available in Kuujjuaq and avoid onerous shipping from the south. The performance of the underground storage has been studied through the DST module in TRNSYS, which does not take into account the groundwater flow advection. The code FEFLOW (Diersch, 2014) will be used to better estimate the heat losses under groundwater advection. Different types of parallel and series connections and geometrical dispositions of the boreholes will be tested to limit the losses due to advection, hence to enhance the heat extraction during the winter.

\section{ACKNOWLEDGMENTS}

The authors would like to thank the Institut Nordique du Québec (INQ) that supports these research activities through the Chaire de recherche sur le potential géothermique du Nord awarded to Jasmin Raymond and the Labex DRIIHM for supporting the activity of Chrystel Dezayes. The Fonds de recherche nature et technologies through the sustainable mining development program and the Observatoire Homme Milieu Nunavik have additionally contributed to this research.

\section{NOMENCLATURE}

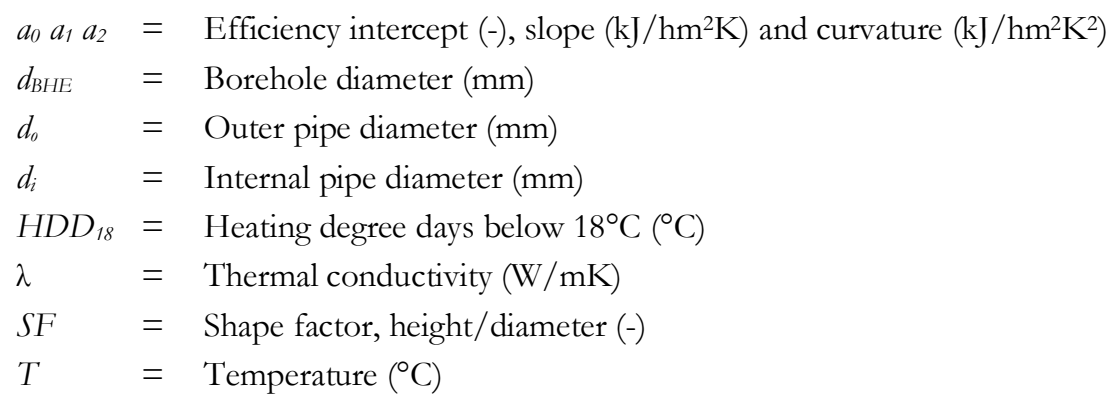

\section{ABBREVIATIONS}

BHE $=$ Borehole heat exchanger
BTES $=$ Borehole thermal energy storage
DHW $=$ Domestic hot water
DST $=$ Duct ground heat storage model developed by Hellström (1989)
ERT $=$ Electrical resistivity tomography
HX $=$ Heat exchanger
HCF $=$ Heat carrier fluid
SH $=$ Space heating
ST $=$ Short term
STST $=$ Short term storage tank
USD $=$ U.S. Dollars

\section{REFERENCES}


Allard, M., Lemay, M. 2012. Nunavik and Nunatsiavut: from science to policy: an integrated regional impact study (IRIS) of climate change and modernization. ArcticNet, Quebec City, QC, 303 p.

Belzile, P., F-A. Comeau, J. Raymond and L. Lamarche. 2017. Revue technologique: efficacité énergétique et énergies renouvelables au nord du Québec. INRS, Centre Eau Terre Environnement, Quebec City, QC, Research Report R1716, 37 p.

Cabeza, L.F. 2015. Advances in thermal energy storage systems - methods and applications. Cambridge, UK: Woodhead Publishing Series in Energy.

Diersch, H.-J.G., D. Bauer, W. Heidemann, W. Rühaak, and P. Schätzl. 2011. Finite element modeling of borehole heat exchanger systems Part 2. Numerical simulation. Computers \& Geosciences, 37(8): 1136-1147.

Diersch, H.J.G. 2014. FEFLOW: Finite element modeling of flow, mass and heat transport in porous and fractured media. Berlin, Germany: Springer.

Flynn, C. and K. Sirén. 2015. Influence of location and design on the performance of a solar district heating system equipped with borehole seasonal storage. Renewable Energy, 81: 377-388.

Fortier, R., M. Allard, J-M. Lemieux, R. Therrien, J. Molson and D. Fortier. 2011. Cartographie des dépôts quaternaires des villages nordiques de Whapmagoostui-Kunjjuarapik, Uminjaq, Salluit et Kunjjuaq. Rapport de synthèse de la phase I, Ministère du Développement Durable, de l'Environnement et des Parcs du Québec, Québec City, GM 65971, 122 p.

Gao, L., J. Zhao and Z. Tang. 2015. A review on borehole seasonal solar thermal energy storage. Energy Procedia, 70: 209-218.

Giordano, N., I. Kanzari, M.M. Miranda, C. Dezayes and J. Raymond. 2017. Shallow geothermal resource assessments for the northern community of Kumijuaq, Québec, Canada. IGCP636 Annual Meeting, Santiago de Chile, Chile, 1-3.

Governement of Canada. 2018. http://climate.weather.gc.ca/climate normals/index e.html accessed in January 2018.

Hellström, G. 1989. Ground heat storage model: manual for computer code. Lund, Sweden: Department of Mathematical Physics, University of Lund.

Hydro-Québec. 2011. Réseaux autonomes, portrait d'ensemble et perspectives d'avenir. Demande R-3776, HQD-13, 35 p.

Klein, S.A., W.A. Beckman, J.W. Mitchell et al. 2017. TRNSYS 18: A Transient System Simulation Program. Solar Energy Laboratory, University of Wisconsin, Madison, USA, http://sel.me.wisc.edu/trnsys.

Lemieux, J-M., R. Fortier, M-C. Talbot-Poulin, J. Molson, R. Therrien, M. Ouellet, D. Banville, M. Cochand and R. Murray. 2016. Groundwater occurrence in cold environments: examples from Nunavik, Canada. Hydrogeology Journal, 24: 1497-1513.

MDDELCC - Ministère du développement durable, environnement et lutte contre les changements climatiques. 2012. Plan d'action sur les changements climatiques 2013 - 2020.

Miranda, M.M., C. Dezayes, N. Giordano, I. Kanzari, J. Raymond and J. Carvalho. 2018. Fracture Network Characterization as input for Geothermal Energy Research: Preliminary data from Kunjjuaq, Northern Québec, Canada. 43 ${ }^{\text {rd }}$ Stanford Geothermal Workshop, February 12-14, Stanford, United States, SGP-TR-213.

Nguyen, A., P. Pasquier and D. Marcotte. 2017. Borehole thermal energy storage systems under the influence of groundwater flow and timevarying surface temperature. Geothermics, 66: 110-118.

Pahud, D. 2000. Central solar heating plants with seasonal duct storage and short-term water storage. Solar Energy, 69(6): 495-509.

Rad, F.M. and A.S. Fung. 2016. Solar community heating and cooling system with borehole thermal energy storage - Review of systems. Renewable and Sustainable Energy Reviews, 60: 1550-1561.

Rad, F.M., A.S. Fung and M.A. Rosen. 2017. An integrated model for designing a solar community beating system with borehole thermal storage. Energy for Sustainable Development, 36: 6-15.

Raymond, J., F-A. Comeau, M. Malo, D. Blessent and I.J. López Sánchez. 2017. The geothermal open laboratory: a free space to measure thermal and hydraulic properties of geological materials. IGCP636 Annual Meeting, Santiago de Chile, Chile, 1-3.

Schmidt, T., D. Mangold and H. Müller-Steinhagen. 2004. Central solar heating plants with seasonal storage in Germany. Solar Energy 76: 165-174.

Sibbitt, B., D. McClenahan, R. Djebbar, J. Thornton, B. Wong, J. Carriere and J. Kokko. 2012. The performance of a high solar fraction seasonal storage district heating system - five years of operation. Energy Procedia, 30: 856-865.

Simard, M., I. Lafrance, H. Hammouche and C. Legouix. 2013. Géologie de la région de Kuujjuaq et de la baie d'Ungava (SRNC 24J, 24K). Québec, Canada: Gouvernement du Québec.

Terziotti, L.T., M.L. Sweet and J.T. McLeskey Jr. 2012. Modeling seasonal solar thermal energy storage in a large urban residential building using TRNSYS 16. Energy and Buildings, 45: 28-31.

Xu, J., R.Z. Wang and Y. Li. 2014. A review of available tecbnologies for seasonal thermal energy storage. Solar Energy, 103: 610-638. 